\title{
Erratum to: Specific post-transcriptional inhibition of mRNA for ligand binding chain of IgE high affinity receptor
}

\author{
Sobia Rana $\cdot$ Ishrat Waheed
}

Published online: 21 April 2010

(C) Springer Science+Business Media B.V. 2010

\section{Erratum to: Mol Biol Rep}

DOI 10.1007/s11033-009-9736-7

This erratum has been initiated as discrepancies with authors were observed after publishing.

Mr. Muhammad Imran was wrongly included in the author group, and is now to be read in the acknowledgement section.
"Centre of Excellence in Molecular Biology, University of the Punjab, LHR" has been added and should be read in the acknowledgement section.

The online version of the original article can be found under doi:10.1007/s11033-009-9736-7.

S. Rana $(\square)$

Molecular and Cell Biology Laboratory, Department of Physiology and Cell Biology, University of Health Sciences (UHS), Khayaban-e-Jamia Punjab, Lahore 54600, Pakistan e-mail: ranacemb@yahoo.com

I. Waheed

Department of Pharmacology and Therapeutics, Riphah Institute of Pharmaceutical Sciences, Riphah International University,

Sector I-14, Islamabad, Pakistan 